Jadwiga Jęcz

Uniwersytet im. Adama Mickiewicza w Poznaniu

solwejga@gmail.com

\title{
Kroki komandora Jerzego Lieberta. Konteksty interpretacyjne
}

\section{Kroki komandora by Jerzy Liebert. Interpretive Contexts}

\begin{abstract}
The history of Don Juan has frequently been the canvas of poetic works, testifying to the undying quality of the myth, and at the same time, to the depth with which the seemingly banal story of the adventures of the corrupt nobleman is imbued. The story of sin and punishment, or, of responsibility for one's deeds, became a creative inspiration for Jerzy Liebert, which resulted in his poem Kroki komandora. This essay adopts a bipolar perspective, treating the poem as, on the one hand, a translation of Alexander Blok's The Commander's Footsteps, which is thus closely related to the Russian original, and on the other hand, as a new and fully autonomous work taking into account the author's biography as well as contexts related to the aesthetics of the times and the artistic millieu of the Skamander group. Keywords: Jerzy Liebert, Alexander Blok, commander, Don Juan
\end{abstract}

Streszczenie: Dzieje don Juana wielokrotnie stanowiły kanwę utworów poetyckich, dowodząc niezwykłej żywotności mitu, a zarazem głębi zawartej w pozornie banalnej opowieści o poczynaniach zdeprawowanego szlachcica. Historia o grzechu i karze, albo o odpowiedzialności za popełnione przewinienia, stała się wypadkową twórczej inspiracji, owocując powstaniem wiersza Kroki komandora Jerzego Lieberta. Autorka szkicu przyjmuje perspektywę dwubiegunową, traktując utwór z jednej strony jako przekład (Kroki Komandora Aleksandra Błoka), pozostający tym samym w ścisłym związku z rosyjskim oryginałem, i jako dzieło nowe, w pełni autonomiczne - uwzględniające biografię autora oraz konteksty związane z estetyką epoki i środowiskiem artystycznym spod znaku Skamandra.

Słowa kluczowe: Jerzy Liebert, Aleksander Błok, komandor, don Juan

Dzieje don Juana ${ }^{1}$ wielokrotnie stanowiły kanwę utworów poetyckich, dowodząc niezwykłej żywotności mitu, a zarazem głębi zawartej w pozornie banalnej opowieści o poczynaniach zdeprawowanego szlachcica. Historia o grzechu

${ }^{1} \mathrm{Z}$ wyjątkiem cytatów i tytułów, w odniesieniu do tytułu grzecznościowego „don” stosowana będzie pisownia małą literą. „Imię" Komandor natomiast w rosyjskim oryginale pisane jest wielką literą; Liebert zdecydował się na małą literę, Jaworski na wielką, co znalazło odzwierciedlenie w niniejszym artykule. Odmienne zasady pisowni obowiązywać będą w odniesieniu do „imienia” Kamienny Gość (oba człony wielką literą bez względu na to, o jakim utworze będę pisała). Kiedy mowa będzie o posągu z utworów innych niż przed chwilą wspomniane, 
i karze, albo o odpowiedzialności za popełnione przewinienia, w wymiarze moralnym (krzywda oszukanych kobiet) zderzonej ze złamaniem - w pewnych obszarach kultury ${ }^{2}$ - prawa (zabójstwo Komandora) stała się wypadkową twórczej inspiracji, owocując powstaniem na gruncie polskim Don Juana i Doñy Anny Marii Pawlikowskiej-Jasnorzewskiej, Don Juana Jana Lechonia, Nad grobem Don Juana Tenorio Tadeusza Micińskiego i wiersza *** (Zbladta twarz Don Żuana, gdy w ulicznym mroku) Bolesława Leśmiana, na gruncie obcojęzycznym natomiast między innymi Don Juana w piekle Charlesa Baudelaire’a i poematu Don Juan George'a Byrona. Niemniej w kontekście tematu artykułu na szczególną uwagę zasługuje utwór Szagi Komandora (Kroki Komandora) Aleksandra Błoka (1910-1912).

Artykuł ma charakter kulturowo-komparatystyczny. Ze względu na niejednoznaczny, w mojej opinii, status utworu Lieberta zdecydowałam się na przyjęcie perspektywy dwubiegunowej, traktując Kroki komandora z jednej strony jako przekład, pozostający w ścisłym związku z rosyjskim oryginałem, i jako dzieło nowe i w pełni autonomiczne - odzwierciedlające działalność poetycką i biografię autora oraz uwzględniające konteksty związane z estetyką epoki i środowiskiem artystycznym spod znaku Skamandra. Pamiętać trzeba o charakterystycznych dla Liebertowskiej poezji motywach i relacjach zachodzących między Krokami komandora a innymi wierszami jego autorstwa powstałymi w tym samym okresie twórczości.

Truizmem jest przypominanie, że każdy przekład jest dziełem nowym i niezależnym, ukazującym interpretację tłumacza i upominającym się o osobną analizę, pozostającym w oczywistej łączności z oryginałem (tekstem wyjątkowym i niezmiennym), a przy tym, na zasadzie paradoksu, więź tę zrywającym. Dowcipne stwierdzenie jednego z bohaterów Patersona Jima Jarmuscha: „Poezja w tłumaczeniu to jak prysznic w płaszczu przeciwdeszczowym" dyskredytuje wartość przekładu. Zadaniem tłumacza - pośrednika między autorem i czytelnikiem - jest odwzorowanie tekstu; w wypadku oryginału temat zostaje podany przez twórcę. Trafna wydaje się uwaga Joanny Kubaszczyk podążającej za myślą Agnieszki Dody-Wyszyńskiej: „Przekład jest czymś mniej niż mimesis, bo w wielu miejscach odbiega od oryginału. Nie jest czystym naśladowaniem, lecz twórczym, zmierzającym do osiągnięcia podobieństwa przetworzeniem i w tym sensie jest czymś więcej niż mimesis" ${ }^{3}$. Warto przy tym pamiętać o możliwej wielokrotności przekładów. W przypadku wiersza poświęconego don Juanowi wspomnieć trzeba o przekładzie tekstu Błoka dokonanym w 1946 roku przez Kazimierza Andrzeja Jaworskiego.

stosowany będzie zapis wielką literą. Do kwestii zapisu „imienia” Komandora (konkretnego bohatera) / komandora (typu postaci) powrócę w końcowej części artykułu.

${ }^{2}$ W Kamiennym Gościu Aleksandra Puszkina don Juan zabija przeciwnika w pojedynku, co było wówczas zakazane. W Don Juanie... Moliera protagonista skąpi szczegółów, choć wiadomo, że sprawa zabójstwa została umorzona.

${ }^{3}$ J. Kubaszczyk, Przektad jako przedmiot przedstawiajacy: ku ontologicznej definicji przekta$d u$, „Przekładaniec” 2016, nr 32, s. 205. 
Tłumacze Błoka zwracali uwagę na uboższy od rosyjskiego polski „zakres melodyczny” i częstą niemożność oddania melodyjności („muzyczności”) treści oryginału. Problem eufonii pokrótce scharakteryzowała Jadwiga Szymak-Reiferowa:

Jak Błok brzmi po polsku? Znającemu melodię oryginału trudno nieraz pogodzić się z polską - jakby nieco uboższą - gamą. Z drugiej strony jednak muzyczne brzmienie wierszy Błoka, tak oczywiste w języku rosyjskim, po polsku może okazać się o ton za mocne, zbyt natrętne, gdyby tłumacz chciał być pod tym względem szczególnie wierny. Zresztą, nie ma reguły, jest indywidualny talent tłumacza i materia słowa w dwóch językach, raz mniej, raz bardziej oporna. Nie umiem sobie wytłumaczyć, dlaczego retoryczność Scytów doskonale mieści się w języku polskim, a nastrój i muzyka Nieznajomej - nie 4 .

Poezję Błoka zaczęto w Polsce tłumaczyć w roku 1918 z inicjatywy Juliana Tuwima i od tego momentu aż do wybuchu wojny powstało siedem przekładów. Utwory autora Odwetu tłumaczyli: Jan Lechoń, Jerzy Liebert, Kazimierz Wierzyński, Józef Czechowicz, Mieczysław Jastrun, Wacław Denhoff-Czarnocki, Leonard Podhorski-Okołów. W latach trzydziestych po Błoka sięgnęli Włodzimierz Słobodnik, Kazimierz Andrzej Jaworski, Józef Łobodowski, Karol Husarski i Seweryn Pollak. Wypada też wspomnieć o Karolu Winawerze i Wiktorze Woroszylskim5 . Co ciekawe, zanim jeszcze wzięto na warsztat jego poezje, Błok interesował się polską kulturą. Więzi łączące autora Odwetu z polskimi autorami sięgają czasów, kiedy ciotka Błoka tłumaczyła Henryka Sienkiewicza, a on sam czytał utwory Adama Mickiewicza, Zygmunta Krasińskiego, Juliusza Słowackiego, Stanisława Przybyszewskiego, Jana Lemańskiego i Jerzego Żuławskiego ${ }^{6}$.

Szagi Komandora pisał Błok w latach 1910-1912 roku, dedykując wiersz W.A. Sorgenfrejowi ${ }^{7}$ i odnotowując w Dziennikach, że spotkał się z ostrą krytyką Wiktora Burienina, który w felietonie Nowoje wriemia zamieścił parodię utworu („Burienin zmiażdżył mnie za Kroki komandora. Wieczorem... chandra” - zanotował 24 listopada 1912 roku $\left.^{8}\right)$. Błok tworzył w czasach niespokojnych i przełomowych. Opublikowany w 100 . rocznicę urodzin poety artykuł Michaiła Dudina (1980) ${ }^{9}$ utrzymany w tonacji pochwalnej, żeby nie powiedzieć, poddańczej, dowodzi mocnej pozycji, jaką w sferze kultury zajmował

${ }^{4}$ J. Szymak-Reiferowa, Jak Btok brzmi po polsku?, „Literatura Radziecka” 1980, nr 11, s. 150.

5 Por. A. Legeżyńska, Interpretacja translatorska w polskiej serii ttumaczeń „Dwunastu” Aleksandra Btoka, „Studia Rossica Posnaniensia” 1979, nr 11, s. 13-25.

${ }^{6}$ T. Poźniak, Aleksander Btok w kregu spraw polskich, „Literatura Radziecka” 1980, nr 11, s. $154-160$.

7 Nie udało mi się ustalić pełnej wersji imion.

8 A. Błok, Dzienniki 1901-1921, tłum. M. Leśniewska, Kraków 1974, s. 142. Kolejne cytaty wszystkich utworów Błoka z tego wydania.

9 M. Dudin, Rzecz o Aleksandrze Btoku, „Literatura Radziecka” 1980, nr 11, s. 106-116. 
obok Aleksandra Puszkina i Michaiła Lermontowa oraz Nikołaja Niekrasowa i Fiodora Tiutczewa. Skarcony za więzy łączące go z symbolistami w 1903 roku opublikował Fabrykę, oddając tym samym hołd „umęczonym masom”. Stopniowo, żeby wspomnieć chociażby o Sepie, Kulikowym Polu, Dwunastu i artykułach drukowanych na łamach prasy, zrywał kontakty ze zwolennikami starego porządku (w tym także z rodzina) i w 1910 roku ostatecznie zadeklarował, że nie chce mieć już nic wspólnego z symbolistami. W latach 1910-1912 pisał Kroki Komandora. Gdyby interpretować wiersz, co wydaje się zdecydowanym nadużyciem, w odniesieniu do ówczesnych politycznych poglądów poety, okazałoby się, że don Juan przegrywa w myśl koncepcji o niemającej szans przetrwania, samodzielnej jednostce; w myśl potępienia indywidualizmu. Ze względu na kontekst kulturowy, wykazujący zdecydowanie silne powiązania z tradycją i mitem Zwodziciela, byłoby to jednak namalowane stanowczo zbyt grubą kreską. Nie tutaj należy szukać korzeni inspiracji poety postacią i historią don Juana.

Poezja Błoka była niejednorodna i tylko reżimowi autorzy okresu radzieckiego mogli ją interpretować wyłącznie przez pryzmat przemian ustrojowych. Kroki Komandora stanowiły wypadkową zainteresowań kulturą i tradycją rosyjską i nierosyjską, nakazującą włączyć w ramy poezji zapożyczenia z wierzeń ludowych („Nie mnie kochasz, Dziwożono” z wiersza *** [Przypędzita stepem gtuchym]) i utworów literackich: Williama Szekspira (Pieśn Ofelii, Ofelia w kwiatach, ${ }^{* * *}$ [Jam Hamlet]), Prospera Mériméego / George'a Bizeta (Carmen), mitologii (,Jak mądry Edyp spójrz Sfinksowi w twarz” z poematu Scytowie) i Biblii („Przechodzi, kryjąc się, Salome/ Z mą krwawą głową w splocie rąk" - Wenecja). Wśród tej grupy znalazło się miejsce dla don Juana, co łączyć także można z wpływem Puszkina, najsłynniejszego rosyjskiego autora utworu poświęconego Zwodzicielowi. Linia przecięcia Błokowskich fascynacji i wciąż uśpionych, choć jawnie zakwestionowanych, dążących do odrodzenia pierwiastków symbolizmu, stanowiła podatny grunt do powstania Kroków Komandora. Symbolizm uwidocznia się tutaj w scenerii wiersza: don Juan miota się rozpaczliwie, momentami nieomal popada w szaleństwo, zmarznięty i przerażony. Świat Błoka jest przecież światem tragicznych sprzeczności. Jak pisał Seweryn Pollak: „Nie na próżno ustawicznym motywem jego wierszy jest sobowtór, szydzący i drwiący, starzec naśladujący młodzieńca, Arlekin - Arlekina, Sobowtór - tragiczny cień, równie realny i równie złudny" ${ }^{10}$. I chociaż odgłos kroków ożywionego posągu nie jest złudzeniem don Juana, Błok mógł wpleść w Kroki Komandora wątki biograficzne i ukazać w postaci przeraźliwie samotnego i rozdartego wewnętrznie Zwodziciela własne niepokoje. Był przecież jednym z tych, których poezje pełniły funkcję osobistego dziennika:

10 S. Pollak, Postowie [w:] A. Błok, Poezje, oprac. S. Pollak, Kraków 1981, s. 423. O niepokoju wewnętrznym poety w kontekście środowiska rodzinnego i uczuciowego rozdarcia zob. S. Kułakowski, Trzy mitości Aleksandra Btoka [w:] K.A. Jaworski, W kregu Kameny, Lublin 1973 , s. 362-367. 
Spokojne i na pozór unormowane życie poety nie pokrywało się z niezwykle intensywną, trudną i zagmatwaną biografią wewnętrzną, która znalazła swe odbicie w twórczości artystycznej. Odtworzył ją sam Błok, układając wiersze w trzytomowym wydaniu liryki z 1911-1912 r. według określonego klucza. Całość miała stanowić swoistą „powieść poetycką”, w której poszczególne wiersze tworzą cykle, te zaś księgi trylogii, będącej spowiedzią i dziennikiem poety, namiętną i niezwykle szczerą relacją o wszystkich wzlotach i upadkach, zwycięstwach i klęskach, tragicznym rozdarciu świadomości oraz rozdźwięku między marzeniem a rzeczywistością, realnym światem a światem „wyższych idei”, życiem a sztuką, prorokiem a poetą, dążeniem do ideału a niemożnością jego osiągnięcia ${ }^{11}$.

Niepokój Błoka znalazł odzwierciedlenie $\mathrm{w}$ wielu wierszach, również w tych, w których, jeszcze przed powstaniem Kroków Komandora pojawił się motyw kamienia. W 1903 roku w wierszu [- Spokój panuje w narodzie?...] lud „skamieniał” (tłum. M. Buczkówna), a w kompozycji [Przystań milczqca. I ziemia tuż...] (tłum. J. Czechowicz) podmiot liryczny słyszy polecenie, aby „na morzu stawić świecę na głaz”. Dwa lata później w Swobodzie jesiennej (tłum. W. Słobodnik) Dziad jest wleczony „przez drogę kamienną”. Niemniej są to przykłady niezwiązane bliżej z Komandorem, w przeciwieństwie do pozbawionego tytułu utworu [Śróddzienne cienie migaja ulotnie...] (tłum. S. Pollak) z roku 1902; w jednym wersie dwukrotnie (nieświadomie?), zapowiadając narodziny innego wiersza, a przy tym i przybycie ożywionego posągu, podmiot liryczny posługuje się przenośnią:

I rozświetlone są cerkiewne stopnie,

I kroków twoich czeka żywy kamieńn ${ }^{12}$.

Żywy - jakkolwiek by było - kamień z Kroków komandora autorstwa Lieberta został natomiast opisany w trzecim (po Drugiej ojczyźnie, 1925; i Gustach, 1930) zbiorze Kotysanka jodtowa (1932, wydanie pośmiertne). Poeta sięgnął po Szagi Komandora w 1930 roku. Zasadniczo twórcę Drugiej ojczyzny uznaje się za jedynego autora przekładu, nieświadomie uniemożliwiając dotarcie do szerszego grona odbiorców propozycji Kazimierza Andrzeja Jaworskiego. A podjęta przez niego translatorska próba (Kroki Komandora) opublikowana na łamach „Kameny” w 1946 roku $^{13}$ zasługuje na uwagę nie mniejszą niż kompozycja poetycka Lieberta. Trudno ocenić, która z wersji jest bliższa oryginałowi, i sądzę, iż powinno się je traktować w kategoriach wzajemnego uzupełnienia. Przykładowo w ostatnim wersie

11 Z. Barański, Aleksander Btok [w:] Literatura rosyjska w zarysie, red. Z. Barański, A. Semczuk, Warszawa 1976, s. 695-696.

12 A. Błok, Poezje, oprac. S. Pollak, Kraków 1981, s. 31.

13 Tenże, Kroki Komandora, tłum. K.A. Jaworski, „Kamena” 1946, nr 8-10, s. 217. 
Jaworski oddaje Błokowską puentę w sposób niemalże dosłowny, a „imię” gościa z zaświatów (tak jak Błok) - w przeciwieństwie do niepokornego Lieberta $^{14}$ - zapisuje wielką literą. Nie przeszkadza mu to jednak w nieuznawaniu sugestii Błoka, aby - przy założeniu, iż tłumaczenie opublikowane w „Kamenie” stanowi odwzorowanie wersji z rękopisu ${ }^{15}$ - stosować pisownię „Don” Juan (Jaworski zapisuje małą literą) i na tym polu przegrywa walkę z dokładnością translatorską Lieberta (z wyjątkiem pierwszego wyrazu w wersie). Ponadto w strofie pierwszej u Lieberta podmiot liryczny, tak jak $\mathrm{w}$ rosyjskiej wersji, zadaje pytanie:

Cóż zostało z twej swobody niedorzecznej,

Don Juanie, gdyś poznał strach?

(wersy 3-4)

podczas gdy u Jaworskiego pojawia się stwierdzenie:

Przepełniła się twych nieprawości miara, don Juanie, kiedyśs poznał strach.

Zwraca uwagę bardziej dosadna, nieuprawniona w wypadku dosłownego potraktowania oryginału, charakterystyka Kamiennego Gościa u Jaworskiego:

Czyj to w lustrach odbił się na chwilę

wyraz twarzy tak okrutny, zły?

(wersy 13-14)

Opis zaproponowany przez Lieberta tchnie duchem zdecydowanie większej łagodności:

Czyjeż rysy srogie rosną w szkłach,

W zwierciadlanych szkłach nieruchomieją?

Wspomnieć jeszcze można o zastosowanym przez Lieberta (w. 33-34) neologizmie „rozświt”: „Wśród przepychu o rozświcie strach porywa”. Jaworski poprzestaje na zaproponowanym przez Błoka „świtaniu”: „O świtaniu strasznie wypełzają cienie/ służba śpi i blednie nocy zrąb”.

${ }^{14}$ Wszystkie cytaty z Kroków komandora Lieberta pochodzą z pierwszego wydania Kotysanki jodtowej: J. Liebert, Kotysanka jodtowa, Warszawa 1932.

${ }^{15} \mathrm{~W}$ późniejszym wydaniu redaktorzy zbioru wierszy Jaworskiego zdecydowali się na zapis „Don Juan”. Por. Od Łomonosowa do Jewtuszenki, wybór, tłum. K.A. Jaworski, Lublin 1972, s. 289. 
Pytanie, w jak dużym stopniu Lieberta bezpośrednio zainspirował wiersz Błoka, a jak istotny wpływ wywarł na niego spektakl Don Juan Tenorio z 1924 roku, najprawdopodobniej pozostanie bez odpowiedzi. Być może nie zdecydowałby się opisać historii uwodziciela, gdyby dwukrotnie w Teatrze Narodowym nie oglądał sztuki Joségo Zorrilli ${ }^{16} \mathrm{w}$ reżyserii Teofila Trzcińskiego i scenografii Wincentego Drabika, z rewelacyjną - co podkreślał także w swych Dziennikach Jan Lechoń - główną rolą Józefa Węgrzyna. W listach do Bronisławy Agnieszki Wajngold Liebert kilkakrotnie dawał wyraz zainteresowaniu sztuką. Pisał 29 grudnia 1925 roku, naruszając zasady odmiany gramatycznej: „Wiesz, droga, wyszedł Don Juan Zorilla [pisownia oryg. - J.J.] i gdy tylko będę miał pieniądze, kupię sobie tę książkę". Zaledwie kilka dni później był już w posiadaniu dramatu w wolnym przekładzie Stanisława Miłaszewskiego i zachwycony informował, że „[sztuka - J.J.] nic, siostrzyczko, nie traci przy czytaniu. I z takim zaparciem wchłania się czar słów Zorilla. Gdybyś chciała, to po przeczytaniu prześlę ci ją”. O zamiarze przesłania książki pisał Liebert jeszcze kilkakrotnie: 13, 30 i między 22 a 27 stycznia 1926 roku. Ponadto na początku stycznia na wieść, iż Miłaszewski napisał komedię, podekscytowany stwierdzit: „Jeśli będzie ona taka, jak tłumaczenie Don Juana, to możemy się

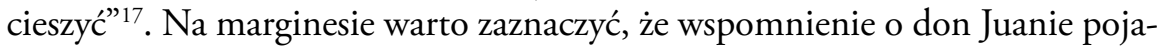
wiło się u Lieberta jeszcze przed napisaniem Kroków komandora. W 1929 roku w dedykowanym Ludwikowi Bujalskiemu i traktującym o leksykalno-metaforycznym bogactwie języka Przekroju fantastycznym (Gusta), oprócz uwiecznionych w kulturze postaci-symboli, takich jak Hamlet czy Faust wymienia się:

Ślady wszystkich nadirów naszych i zenitów

Warstwice Don Juanów z odciskami kobiet

Ofelie - złomy kredy - niosące na sobie

Florę rzek, ziele duńskie - wianki litofitów... ${ }^{18}$

Fascynacja Lieberta utworem Zorrilli nie budzi wątpliwości, niemniej należy pamiętać o skrajnie odmiennym finale hiszpańskiego dramatu i wiersza Błoka. Liebert pracował nad utworem o don Juanie potępionym, mając w pamięci złagodzoną puentę sztuki Zorrilli. W Don Juanie Tenorio protagonistę od wyroku wiecznego potępienia ratuje wierna miłość doñy Inés, której dusza - w końcowych fragmentach sztuki - wraz z duszą ukochanego unosi się

16 Stosowana często (nie tylko przez Lieberta) pisownia nazwiska hiszpańskiego twórcy przez jedno „r” (Zorilla) jest o tyle kłopotliwa, iż przywołuje skojarzenia z przypominającym skunksa rodzajem drapieżnika (lctonyx) z rodziny łasicowatych. Występujące gatunki to na przykład zorilla paskowana (lctonyx striatus) czy zorilla libijska (lctonyx libyca).

${ }^{17}$ Cytaty z listów poety pochodzą z książki: J. Liebert, Listy do Agnieszki, oprac. S. Frankiewicz, Warszawa 2002, s. 292, 295, 304.

${ }^{18}$ Cytaty z wierszy Lieberta pochodzą z: J. Liebert, Poezje, wstęp B. Ostromęcki, Warszawa 1983 (podkr. - J.J.). 
do nieba. Oglądając spektakl po raz drugi, tym razem w towarzystwie Antoniego Słonimskiego, Liebert po raz kolejny dał się poznać jako twórca poezji głęboko osadzonej w kontekście moralno-religijnym. W jednym z listów pisał o Bożym Miłosierdziu i związanym z tym odkupieniem; motywie, którego Słonimski w historii don Juana nie potrafił zaakceptować:

Jemu [Słonimskiemu - J.J.] to rozwiązanie wydaje się zbyt proste. Zawsze, powiada, w katolickich sztukach, jest miłość, która zwycięża, upraszcza wszystko, jest Bóg ze swoim miłosierdziem. S. boi się po prostu powiedzenia miłość, wydaje mu się to słowo czcze. I ja mu się nie dziwię. Bo żeby to słowo można było spod serc bez fałszywego wstydu wydobyć, trzeba mieć w sercu Boga. Bojaźń ogromna i męstwo wielkie. Gdyby Bóg choć raz dotknął S., mógłby bez przymknięcia oka patrzeć na grzech człowieka i miłosierdzie Boże $(. . .)^{19}$.

Niemożność uznania przez Słonimskiego dramatopisarskiej (i dramaturgicznej) koncepcji przebaczenia korzącemu się don Juanowi wszystkich grzechów oznacza trwanie w pogańskim kręgu przewinienie-konieczność kary, bez możliwości odpokutowania i zadośćuczynienia. Już Plutarch pisał w Moraliach:

Jak wielką niedorzeczność sprawia (...) ta zwłoka i ociąganie się bóstwa! Mianowicie powolność w działaniu odbiera wiarę w opatrzność (...) [S]kłonność do zła, jeśli za każde uchybienie i fałszywy krok otrzyma cięgi i powściągającą karę, może stanie się oględniejsza, pokorniejsza i ulęknie się boga jako przełożonego nad ludzkimi czynami i uczuciami a nie odraczającego kary sędziego ${ }^{20}$.

W kulturze wykształciły się dwa typy postaci don Juana: potępionego i ukaranego śmiercią (don Juan Tenorio) i nawróconego, pokutującego w klasztorze (don Juan de Marańa). Zorrilla wprowadził swoisty eklektyzm, nadając protagoniście nazwisko Tenorio i nie skazując go na pośmiertne męki. Już sam zresztą fakt, iż bohater umiera (jak Tenorio), a trafia do nieba, dowodzi nowatorstwa, a przynajmniej ${ }^{21}$ ciekawego pomysłu Zorrilli. To bowiem zakończone tragedią protagonisty prowokacyjne wystawianie Boga na próbę i całkowite pogrążenie się w grzechu stało się rudymentarną cechą charakteru postępowania uwodziciela Tenorio i przetrwało $\mathrm{w}$ większości znanych reprezentacji literackich od XVII wieku (wówczas to Tirso de Molina napisał pierwszy utwór dramaturgiczny poświęcony don Juanowi Tenorio), podobnie jak historia nawrócenia rozpustnika de Maraña rozpowszechniła się dwa stulecia później za sprawą opowiadania Czyśćcowe dusze Prospera Mériméego.

19 J. Liebert, Listy do Agnieszki, dz. cyt., s. 237.

20 Plutarch, Moralia, rozdział: O odwlekaniu kary przez bogów, tłum. Z. Abramowiczówna, Warszawa 1988, s. 83-84.

${ }^{21}$ Ze względu na ogromną liczbę ( $w$ większości nieprzetłumaczonych) dramatów nie są mi znane wszystkie literackie wersje mitu don Juana. 
Zainteresowanie Lieberta poezją rosyjską unaoczniło się w inspiracjach twórczością Sergiusza Jesienina, Michaiła Lermontowa i Fiodora Sołoguba oraz w przekładach (początkowo niesamodzielnych, lecz tworzonych za pośrednictwem Juliana Tuwima, Jana Lechonia i Władysława Broniewskiego) z Anny Achmatowej, Afanasija Feta, Fiodora Tiutczewa, Aleksandra Puszkina, Siemiona Nadsona i oczywiście Błoka ${ }^{22}$. Twórczość autora Ostatnich dni caratu Liebert przybliżył polskiemu czytelnikowi za sprawą Sępa (Kotysanka jodtowa), Dolor ante lucem (Gusta), ${ }^{* * *}$ ([Ostatni btysk zachodu zgast...], Kotysanka jodtowa) i Kroków komandora. W wierszach tych zwraca uwagę wyeksponowanie pierwiastków eschatologicznych; mimo wkomponowania obrazu śmierci w ramy przyrody pobrzmiewają tutaj echa społeczno-egzystencjalnych niepokojów autora. W Sępie „wojna grzmi, szaleje rokosz, sioła płoną”, a w Ostatnim btysku... „dźwięk ten w skargę rósł, żałobnym wtórząc lękiem”. Typowe dla Lieberta tematy w podobnym stopniu charakteryzują wiersze Błoka i pozwalają wyznaczyć punkt wspólny na mapie działalności twórczej obu poetów. Pisała Anna Sobieska:

W wybranych [przywołanych tłumaczeniach z Błoka - J.J.] przez Lieberta utworach zawierało się coś bardzo znamiennego dla istoty „błokowszczyzny” - a mianowicie prorockie przeczucia Apokalipsy, niedostępny i dręczący poetę lęk przed karą za grzech niewierności wobec ideałów, poczucie winy, oczekiwanie zbliżającej się odpłaty za dokonane wybory, jakiejś zemsty ze strony siły wyższej, a także paraliżujący strach przed śmiercią jako pustką. Wiersze te jako zapis emocji rozbudzanych przez złe duchy, jako dowód opętania przez demona trwogi i smutku - jeśli wierzyć Fłorienskiemu, twierdzącemu za licznymi duchownymi, świętymi i twórcami literatury hagiograficznej, że „pełna lęku tęsknota i trwoga to istotny symptom opętania przez demony - mogłyby stanowić swego rodzaju motto dla Liebertowskich zmagań z pokusami, zwłaszcza tych zapisanych w wierszach ostatnich"23.

Pozostając w kręgu literatury rosyjskiej, chciałabym krótko omówić problematykę wersyfikacyjną wierszy autora Kotysanki jodtowej. Podlegając wpływom ówczesnej, chętnie rozpowszechnianej za sprawą skamandrytów mody na wprowadzanie asonantycznych zakończeń wersów, być może Liebert był jednym z tych, którzy - jak uważa Leonard Podhorski-Okołów - ulegli sugestiom Romana Jakobsona i innych teoretyków rosyjskich ${ }^{24}$. W sposób

22 P. Nowaczyński, O miejscu Lieberta w polskiej poezji religijnej [w:] tegoż, Studia z literatury XX wieku, Lublin 2004, s. 101. Anna Sobieska o pośrednictwie nie wspomina, za to podkreśla mistrzostwo translatorskich prac Lieberta. Por. A. Sobieska, Wokót Aleksandra Btoka. Z dziejów polskich fascynacji kultura i literatura rosyjska, rozdział: Pożoga i wir - Jerzy Liebert o chtystowskich „Cwiczeniach pokutnych”, Warszawa 2015, s. 326-327.

${ }_{23}$ A. Sobieska, dz. cyt., s. 329.

24 Por. L. Podhorski-Okołów, W obronie nowych rymów, „Skamander” 1926, nr 44-46. 
oczywisty dopełniałoby to wizerunku poety-pasjonata kultury literackiej Rosji, co uwidoczniło się chociażby w określonym układzie zgłoskowym zastosowanym w pewnych fragmentach Kroków komandora. Liebert tworzy klauzule, w których w artykułowanej w sposób najsłabszy końcowej spółgłosce lub głosce jednego zakończenia czasami odpowiada całkowicie inna, a czasami pokrewna głoska drugiego zakończenia ${ }^{25}$ :

Przelatuje, bryzgiem świateł tnąc mrok,

Motor czarny i cichy jak sowa.

Po komnatach huczy głucho, grzmi miarowo,

Idącego komandora krok...

(wersy 21-24; podkr. - J.J.)

Szymon Pękacki wyodrębnił dwie fazy twórczości Lieberta: a) od 1925 i b) od 1930 roku. Faza druga związana jest bezpośrednio z opublikowaniem Guset, w których nie pojawiają się już konwencjonalne, zbanalizowane metafory spełniające funkcję ozdobników języka poetyckiego, a daje się zauważyć odcięcie od estetyki młodopolskiego impresjonizmu. Ponadto zaczynają pobrzmiewać tony surowe, zaś poeta dąży do maksymalnego sfunkcjonalizowania środków wyrazu i zindywidualizowania własnego stylu ${ }^{26}$. Podobną cezurę zaproponowała Irena Sławińska, z tym zastrzeżeniem, że za zwiastun drugiej fazy uznała rok 1927 - okres „,wstrzemięźliwej, świadomej prostoty” ${ }^{27}$.

Trudno podać w wątpliwość stwierdzenie, że Liebert był autorem religijnym $^{28}$. Głęboko osadzone w kontekście wiary katolickiej utwory z okresu wczesnej (choć w sumie trudno wprowadzać cezurę - umarł w wieku zaledwie 27 lat!) młodości poety tchną duchem szczerych przeżyć religijnych, co z jednej strony łączy się z naiwnością i upoważnieniem odbiorcy do uznania niektórych wierszy zaledwie za preludium do mającej się narodzić samodzielnej (nieopartej na tłumaczeniach) poezji w pełni dojrzałej, w formie, która niestety nie zdążyła powstać, z drugiej jednak - o czym pisali Irena Sławińska, Zbigniew Bieńkowski, Jan Kott i Stefania Skwarczyńska trzeba docenić oryginalność wierszy Lieberta, podobnie jak poetycki zamysł,

${ }^{25}$ Zob. A.M. Szczepan-Wojnarska, „...Z ogniem będziesz się żenit”. Doświadczenie transcendencji w życiu i twórczości Jerzego Lieberta, Kraków 2003, s. 106. Badaczka wyodrębniła też trzy inne typy zakończeń zgłoskowych w poezji Lieberta: 1. Wykazujące całkowitą zgodność spółgłosek i samogłosek z wyjątkiem ostatniej spółgłoski; 2. Wykazujące wokaliczną zgodność końcowych zgłosek szeregów: na przykład tętna/cmentarz, blaszane/kamień; 3. klauzule asonantyczne, które cechują się mniejszą niż w pozostałych wymienionych typach zgodnością dźwiękową. Por. tamże, s. 105-108.

26 S. Pękacki, O liryce Jerzego Lieberta, „Twórczość” 1965, nr 12, s. 82-91.

27 I. Sławińska, Groza stowa (o poezji Jerzego Lieberta), „Znak” 1949, nr 2, s. 127.

${ }^{28}$ Wnikliwe studium poruszające ten problem wyszło spod pióra ks. Stefana Misińca: Ślady na niebie. Duchowa droga Jerzego Lieberta, Kraków 1997. 
aby w wierszach zawrzeć pytanie o kondycję religijną człowieka i jego dramat ziemskiej egzystencjii ${ }^{29}$. Istotna jest zwłaszcza uwaga Sławińskiej, iż Liebert nigdy nie ograniczał się do wyrazu religijnego, ale zawsze podkreślał konieczność doświadczenia poetyckiego i odpowiedzialność za słowo, co było zespolone z poszukiwaniem własnego stylu. Zwłaszcza po roku 1927 skupiał się na stronie formalnej, rezygnując z charakterystycznej ornamentyki słownej i skłaniając się ku zasadzie strukturalnej wiersza ${ }^{30}$. Głęboka wiara autora Kotysanki jodtowej pozostawiła wyraźny ślad także w korespondencji z Bronisławą Agnieszką Wajngold, którą wielokrotnie później upamiętniał; zachowując pozory niedopowiedzeń, zwracał się do adresatki w sposób bezpośredni, lecz osadzony w duchu anonimowości („Ty”), albo po imieniu (nie zawsze prawdziwym), dwukrotnie w 1924 roku opisując ją jako Annę: Do Anny i Serce Anny oraz - najbardziej dosłownie - jako siostrę Agnieszkę (*** [Wszelka taska, której imię...], 1926):

Wszelka łaska Pańska

Niech spłynie na umysł i serce siostry mojej Agnieszki

A gorzki smutek rozstania zabierze ode mnie

Według Piotra Nowaczyńskiego Agnieszka, podobnie jak donna Anna z Don Juana, była dla Lieberta ideałem ucieleśniającym dziewczynę-chrześcijankę i właśnie w ten sposób przedstawił ją, pracując nad wierszem Błoka ${ }^{31}$. Jeżeli rzeczywiście to postać „Anny” W. miał wówczas autor przed oczami, to znaczące może się wydać odejście od puenty zawartej u Błoka w kontekście finału zaproponowanego przez Lieberta. W ostatnich dwóch wersach rosyjskiego oryginału jest mowa o tym, że:

Donna Anna w godzinie Twojej śmierci wstanie

Donna Anna wstanie w godzinie śmierci

natomiast u Lieberta:

Na śmiertelne twoje gody Anna wstanie.

Anna wstanie w śmierci twej czas

[podkr. - J.J.].

Wiele wskazuje na to, że odwołanie do terminologii związanej ze ślubem oddaje ówczesny stan ducha poety zafascynowanego adresatką listów, choć

29 Zob. na przykład Z. Bieńkowski, Legenda i poezja Lieberta [w:] J. Liebert, Poezje, Warszawa 1963, s. 5-19; J. Kott, Katolicyzm liryki Lieberta, „Przegląd Współczesny” 1935, nr 155.

${ }^{30}$ I. Sławińska, dz. cyt., s. 118-133; zob. zwłaszcza s. 128, 131.

31 P. Nowaczyński, Liebert w polskiej liryce religijnej, „Znak” 1971, nr 10, s. 1307. 
już uczuciowo przegranego, gdyż w momencie powstania Kroków komandora siostra Agnieszka od dwóch lat przebywała w klasztorze Sióstr Franciszkanek w Laskach. Wnikliwa lektura Listów nie upoważnia do powtórzenia za Wisławą Szymborską, że jeszcze przed podjęciem decyzji o wyborze życia zakonnego Bronisławy miłość tych dwojga miała charakter zdecydowanie intelektualny („,Byli sobie idealnymi partnerami do wymiany myśli”) $)^{32}$. Być może nawet sama Szymborska zdawała sobie sprawę ze znaczących nieścisłości zawartych w stwierdzeniu i jedynie fakt, iż s. Agnieszka wówczas jeszcze żyła, i niestosownym byłoby wyrażenie innego poglądu, skłonił poetkę do takiej a nie innej wypowiedzi. W utworze Do Anny podmiot liryczny utożsamiany z autorem odmalowuje pozornie łagodne echa wspomnień, mimochodem dając jednak wyraz targających nim namiętności: serce poety jest „wrzące i gwarne”, a serca jego i Agnieszki „niespokojne i dręczone burzą". Nie sposób oddzielić poetyckiej wizji gwałtownych uczuć od silnego kontekstu biograficznego.

Z Listów wyłania się postać Lieberta zakochanego i wyczekującego spotkania z Agnieszką. Z korespondencji z 1925 roku wynika, iż autor Guset poważnie myślał o małżeństwie; z dużą dozą prawdopodobieństwa można stwierdzić, że decyzja kobiety o wstąpieniu do klasztoru dała asumpt do uwikłania się Lieberta ok. 1926 roku w skomplikowane relacje z oficjalnie zamężną (choć żyjącą w separacji) Marią Leszczyńską. Faktu, iż tak bardzo religijny poeta, mimo iż w okresie bezpośrednio po rozstaniu z Agnieszką z trudem, ale jednak zaakceptował sytuację i niespodziewanie decyduje się pogwałcić wyznawane dotąd zasady moralne, nie można rozpatrywać w oderwaniu od zdarzeń wcześniejszych, a mówiąc dokładniej - głębokiego wstrząsu wywołanego utratą ukochanej kobiety.

Fragmenty Kroków komandora wykazują cechy typowe dla drugiego okresu twórczości autora Listów do Agnieszki. Dzięki temu możliwe staje się przeprowadzenie analizy przez pryzmat charakterystycznych wyznaczników Liebertowskiej poezji. Abstrahując od dwukrotnie oglądanego spektaklu, wydaje się, iż nie bez powodu sięgnął po wiersz Błoka w czasie, kiedy chorując na gruźlicę, nieuchronnie zbliżał się ku śmierci. Opisując ostatnie lata życia Lieberta, Stanisław Kot podkreślał silnie obecne motywy eschatologiczne, które - co może budzić zdziwienie - katolicki poeta oswajał nie poprzez wiarę, lecz chorobę. Zainspirowany własnymi doświadczeniami zwrócił się w stronę podjęcia refleksji dotyczącej procesu umierania ${ }^{33}$. Oswajanie śmierci - choćby i nawet poprzez gorzką satyrę (Skazańcy, 1930) - nie ustrzegło go jednak przed odczuwaniem stricte ludzkiego lęku przed nieuchronnym i mającym niedługo nastąpić końcem (Rapsod żałobny, 1930), a ponadto skłoniło do posłużenia się estetyką naturalizmu, o czym świadczy między innymi nieco naiwna Pieśn o zagtadzie (1931):

32 W. Szymborska, Lektury nadobowiązkowe, „Życie Literackie” 1977, nr 13, s. 15.

33 S. Kot, Poezja lęku, „Poezja” 1978, nr 10, s. 14-15. 
Tylko się oczy stają większe

Tylko oddechy coraz prędsze,

Język oblepia gęsta ślina

I nagle zjawia się plwocina

Co istotne, według Leona Pomirowskiego poezja końcowej fazy działalności Lieberta nie ilustruje wyłącznie lęku poety, ale zawiera akcenty humorystyczne, łagodzące przygnębiający ton i ubogacający akt kreacji poetyckiego świata:

Głównym motywem Kotysanki jest proces zamierania. Jak płomiennie jednak pisze ten poeta o swojem [pisownia oryg. - J.J.] wygasaniu, z jaką swobodą i humorem nawet ten proces własnego rozpadu przetwarza na obraz życia. Tkwiące na spodzie każdego wiersza czysto ludzkie roztkliwienie nad swoim losem staje się ostrogą dla wciąż nowej żywotności poetyckiej - w ciągle tej samej pracy kojarzenia, harmonizowania, bratania ${ }^{34}$.

Niemniej podobnie jak Pieśni o zagtadzie cytowanego fragmentu nie sposób odnieść do Kroków komandora. Zabrakło tu miejsca na najmniejszy chociażby element humoru. Strach don Juana, na wzór odczuwanego przez podmiot liryczny Pieśni o zagładzie, również ma charakter fizjologiczny: w żyłach ścina się krew, a w gardle panuje suchość. Istnieją sytuacje, których nie sposób potraktować w sposób żartobliwy.

Liebert zaczerpnął z historii uwodziciela motyw preludium do bezpośredniej, ostatecznej konfrontacji z Kamiennym Gościem. Podobny zresztą zabieg pojawił się u Pawlikowskiej-Jasnorzewskiej (Don Juan i doña Anna), kiedy w ostatnim wersie przywołano hiszpańskie imię ożywionej figury nagrobnej (El Convivador de piedra) oraz w Lechoniowym Don Juanie, gdzie kroki Komandora są doskonale słyszalne. Jednak wspomniani twórcy nie zdecydowali się przedstawić poetyckiej wizji spotkania antagonistów. Zainspirowany Błokiem Liebert poszedł o krok (jak na ironię!) dalej i oto kamienne usta Komandora rozchylają się i zdecydowanie wybrzmiewa wielokrotnie opisywana przez średniowiecznych twórców (historia znieważonej czaszki - wówczas jeszcze nie posągu - którą młody rozpustnik prześmiewczo zaprosił na ucztę) i barokowych (oraz późniejszych) autorów dramatów, fraza ujęta w wersyfikacyjne ramy wiersza:

- Na wieczerzę zapraszałeś, Don Juanie?

Oto masz mnie. Jestem gotów. A ty?

(wersy 27-28)

${ }^{34}$ L. Pomirowski, Nowa literatura w nowej Polsce, Warszawa 1933, s. 82. 
Podstawowa różnica między obrazem wykreowanym przez autora Kotysanki jodtowej a koncepcją dramatopisarzy zasadza się na postawieniu przez Liebertowskiego komandora pytania, w przeciwieństwie do wygłoszenia przez posag zdania w trybie oznajmującym w utworach innych autorów. Podobna kwestia wyłania się podczas analizy zachowania don Juana. W licznych wersjach dramatów rozpustnik, kiedy tylko ochłonął po pierwszym zaskoczeniu (na przykład w Zwodzicielu z Sewilli... wycofał się ze świecą w jednej, a szpadą w drugiej ręce), pozorując spokój (lub rzeczywiście jeszcze w tym momencie nie odczuwając lęku), kordialnie zapraszał na wieczerzę. W dramacie Tirsa de Moliny mówit:

Dla nas obu jadła starczy.

Jeśli przyszło więcej gości,

Każdy z nich odejdzie syty.

Proszę, oto stół nakryty.

Siadajcie ${ }^{35}$.

W Don Juanie... Moliera, zwracając się do służącego, był nie mniej wylewny:

Pić dawajcie. Za zdrowie komandora! W twoje ręce, Sganarelu! Nalejże mu wina. (...) Pij i zaśpiewaj nam coś, aby uczcić komandora ${ }^{36}$.

Podobnie u Zorrilli: „Kielich masz i siadaj do stoła!”37. U Lieberta natomiast:

W odpowiedzi - w gardle więźnie głos.

W odpowiedzi - cisza przeraźliwa.

(w. 29-30)

Już w początkowej fazie spotkania don Juan przegrywa, ulegając paraliżującej sile strachu. Nie pozostał w nim choćby pierwiastek charakterystycznej buty i zamiłowania do podejmowania ryzyka. Zaskakująca zmiana rysu $\mathrm{w}$ psychice protagonisty może zastanawiać również w kontekście złagodzenia pytania zadanego przez kamienny posąg w odniesieniu do wiersza Błoka. W rosyjskim oryginale mowa jest o srogim pytaniu, na które nie ma / brakuje odpowiedzi. Autor Kotysanki jodtowej dopiero w dwóch ostatnich wersach następnej strofy odmalowuje, wzorem Błoka, atmosferę grozy:

Wśród przepychu o rozświcie strach porywa,

Służba śpi i wolno blednie noc.

(w. 31-32)

35 T. de Molina, Zwodziciel z Sewilli i Kamienny Gość, tłum. M. Pabisiak, Wrocław 2000, s. 97.

${ }^{36}$ Molière, Don Juan czyli Kamienny Gość, tłum. T. Boy-Żeleński, Kraków 2003, s. 85-86.

37 J. Zorrilla, Don Juan Tenorio, wolny przekład S. Miłaszewskiego, Warszawa 1925, s. 172. 
W Krokach komandora panuje nastrój lęku, spowodowany nie tylko wyczuwalnym zbliżaniem się ożywionego posągu tego, którego rozpustnik pozbawił życia, ale także zastaną martwą obecnością Anny. Na linii zderzenia trzech czasów rozpaczliwie miota się don Juan, rozdarty między grzeszną przeszłością (i na podstawie fragmentu „Na rozprawę wychodź, stary losie!”, czytelnik powinien dopowiedzieć - świadomością wielu przestępstw, których się dopuścił) a wzbudzającą przerażenie teraźniejszością i tym, co nieuchronnie, dosłownie za moment się wydarzy. Już w następnej chwili nastąpi nieopisana na kartach poezji śmierć uwodziciela, co Jan Kott, również posługując się odwołaniami o charakterze temporalnym, podsumowat:

Don Juan stary! Wydaje się to zaprzeczeniem Don Juana, ale Don Juan, którego nie porwała lodowata ręka Komandora, starzeje się jak my wszyscy. Żył w czasie teraźniejszym, ale teraz jego czas terá́niejszy jest czasem zaprzeszłym: Elwira i Komandor, Izabela i Donna Anna, i wszystkie księżne, i wszystkie praczki, z którymi spał. I wszystkie chłopki, którym obiecywał małżeństwo. Jest tylko jedno miejsce, w którym cały czas przeszły jest z powrotem czasem teraźniejszym i w którym cały zostaje już na zawsze Don Juan i wszystkie osoby komedii, tragedii i opery. Tym miejscem jest Piekło ${ }^{38}$.

Symptomy coraz bardziej zaawansowanej choroby płuc Lieberta znalazły odzwierciedlenie w wierszach ostatniego okresu twórczości. Wypada jednak zauważyć również drugą odsłonę niepokoju poety, związaną z lękiem przed zatraceniem indywidualności kosztem postrzegania i przeżywania przez zbiorowość, zachłannie zazdrosną o najmniejsze choćby przejawy własnego postrzegania i dążącą do nieuchronnej konfrontacji na linii ja (podmiot liryczny)-świat. W Listach do Agnieszki, opisując ówczesny stan ducha, Liebert posłużył się postacią (w tym wypadku można mówić o metaforze) Kamiennego Gościa, podkreślając charakterystyczne dla mitu don Juana Tenorio przybycie (od czego nie ma ucieczki) posągu: „Im większa żądza poznania wielowymiarowości życia, tym coraz bliższy nieuchronny, jak krok Komandora, odgłos idącej samotności" ${ }^{39}$. Stwierdzenie to dowodzi po raz kolejny silnego oddziaływania na poetę historii ukaranego rozpustnika i plastycznej wizji spotkania z ożywioną figurą nagrobną. Na marginesie wspomnieć można o dwóch innych autorach, którzy w epickiej fabule książek zawarli odniesienia właśnie do owej nieuchronności i motywu działań Komandora. W Święcie wiosny Aleja Carpentiera pojawia się fragment: „Ignacio Sánchez Mejía mógł umrzeć tylko tamtego dnia i to tamtego dnia bardzo punktualnie o piątej po południu, tam gdzie byki stawiają się nieubłaganie na spotkania, z punktualnością, również nieubłaganą, Kamiennego Gościa - wymysł

\footnotetext{
38 J. Kott, Don Juan, albo o pożadaniu, „Zeszyty Literackie” 1994, nr 47, s. 88.

39 J. Liebert, Pisma zebrane, t. 1: Poezja-proza, oprac. S. Frankiewicz, Warszawa 1976, s. 589.
} 
hiszpański (...)"; a narrator Madame, alter ego Antoniego Libery, opisując inspekcję (tak zwany nalot) nauczycielki w łazience w celu zidentyfikowania niesubordynowanych palaczy papierosów, zapytał: „I kto wkroczył do klozetu niczym legendarny Komandor?”“0 . Być może więc Komandor niedługo na trwałe zagości w języku jako komandor (na wzór już nie don Juana, lecz donżuana) jako symbol nieubłaganego mściciela krzywd. Jednakże to już temat na inną rozprawę.

Zwraca uwagę obecny w Krokach komandora motyw piania koguta ${ }^{41}-$ wykorzystany także w Śnie (1930) i Bożej nocy (1928-1929) - ewokujący skojarzenia z historią zaparcia się Piotra i pozyskanej nagle świadomości winy. Biblijny kogut zapiał, by wypełniły się słowa Jezusa, a w dalszej perspektywie, aby uświadomić głęboko wierzącemu człowiekowi jego słabość w obliczu strachu. U Lieberta potraktowany poetycko „śpiew” koguta przypomina z jednej strony o wymagającej dopowiedzenia przemowie Komandora na temat nieuchronności Bożego sądu, z drugiej natomiast - tym razem wyrażonych bezpośrednio słowach o wypełnieniu się obietnicy dotyczącej przybycia na wieczerzę. W kontekście metaforyki biblijnej termin „wieczerza” uwalnia kolejne sensy, nakazując dostrzec konotację między wielkoczwartkowym preludium do ukończenia zbawczej misji i wstępem do dopełnienia miary sprawiedliwości. Zdecydowanie nieprzypadkowy wydaje się bowiem wybór akurat tego polskiego słowa, a nie na przykład „kolacji” dopuszczalnej pod względem znaczeniowym. Fragment utworu Błoka równie dobrze można by przecież przetłumaczyć:

Wezwałeś mnie na kolację.

Przybyłem. Czy jesteś gotów?

W prowadzenie motywu koguta spełnia w wierszu także inną funkcję. Oto don Juan dowiaduje się, że został pozbawiony możliwości podjęcia trudu (i łaski) pokuty. Piotr dojrzał duchowo, don Juanowi zabrakło czasu. I chociaż stwierdzenie, że już nic więcej się nie wydarzy, nie oznacza bynajmniej ucieczki od końcowej fazy moralnego rozliczenia - co w tej sytuacji okazałoby się ratunkiem, w myśl koncepcji, iż lepiej nic nie odczuwać, niż odczuwać cierpienie - jest to kres funkcjonowania w sferze typowo ludzkiej.

Wiarołomco, na cóż ci ten dźwięk?

Przyszedł kres! Nie stanie się nic więcej!

40 A. Carpentier, Święto wiosny, tłum. J. Carlson, Warszawa 1997, s. 231-232; A. Libera, Madame, Kraków 2008, s. 41.

${ }^{41}$ Kogut w poezji Lieberta doczekał się przede wszystkim upamiętnienia w Kogutach, których interpretacja stała się pretekstem do wymiany skrajnie odmiennych poglądów krytyków literackich. Zob. P. Nowaczyński, Ktopoty z kogutem. Z dziejów poetyckiego obrazowania, „Twórczość" 2000, nr 3, s. 106-112. 
Donna Anna śpi, na krzyż złożywszy ręce,

Donna Anna śni wieczny sen...

(w. 10-12)

Omawiając wiersz Święta Katarzyna Genueńska (1925), Marcin Całbe$\mathrm{cki}^{42}$ dostrzegł interesującą paralelę między działaniami tytułowej bohaterki a przybyciem Komandora - emanacji odwiecznej sprawiedliwości. Przedmiotem rozważań czyni:

a) moment interwencji spoza ziemskiego świata. Koncentruje się wówczas na postaci świętej, która przybywa w celu poskromienia czekającego zresztą na to silnie zindywidualizowanego twórcy („Bij w serce me jak w naczynie, co samo sobie wystarcza”)

b) moment, w którym pozornie destrukcyjnej sile własnych działań podmiot liryczny nadaje charakter nowego porządkư ${ }^{43}$.

Analogię do przybycia Kamiennego Gościa Całbecki interpretuje, opierając się na recenzowanych przez Lieberta Piesniach fantastycznych Kazimierza Wierzyńskiego:

Śledzony przez recenzenta [Lieberta - J.J.] motyw przemiany (...), jaka nastąpiła w twórczości autora Wiosny i wina, znajduje swą analogię w doświadczeniu Don Juana. Ta właśnie narracja, zaczerpnięta zapewne z Puszkina, gdyż zorientowana na ostatnie chwile życia bohatera i przedstawiona głównie w perspektywie wizyty „kamiennego gościa”, ponownie wykorzystuje motyw przywrócenia porządku świata naruszonego za sprawą lekkoducha i „fanatyka urody życia”. Natomiast motyw kary za grzechy, szczególnie owa domagająca się odkupienia w ogniu czyśćcowym poena senus, tworzą wyraźną analogię pomiędzy potępionym przez tyreusza i dręczonym przez Świętą poetą a obiektem zemsty Komandora Don Juanem ${ }^{44}$.

Powracający w twórczości Lieberta wątek zleconej przez Boga misji z jednej strony stanowi uzupełnienie wizerunku poety-katolika, z drugiej natomiast ilustruje dramatyczny niepokój twórcy dążącego do dochowania wierności idei własnego postrzegania rzeczywistości. Poeta broni się przed narzucaniem jedynej, słusznej wizji, a przy tym z niezrozumiałą niekonsekwencją oczekuje przybycia Świętej, realizującej Boże zamierzenia.

${ }^{42}$ M. Całbecki, „Czarna kropla nieskończoności”. Fenomen lęku w poezji Jerzego Lieberta, Wtadystawa Sebyty i Aleksandra Rymkiewicza, Wrocław 2008, s. 92, rozdział: "Jerzy Liebert”, Jerzy Liebert, - - - Harmonia, przemoc i ironia jako egzystencjaty twórczości Jerzego Lieberta.

43 Tamże.

${ }^{44}$ Tamże. 
Podmiot liryczny Kroków komandora ulega metamorfozom. Jest nim Los, utożsamiany z sumieniem - wewnętrznym monologiem protagonisty lub Bogiem (strofy 1, 3, 5, 10); następnie don Juan bezpośrednio wzywający imienia donny Anny (4, 5) i wreszcie Kamienny Gość (7); pozostałe zwrotki $(2,6,8)$ mają charakter opisowy i uznać je można za wypowiedź podmiotu lirycznego - utożsamianego z autorem wiersza. Niezwykle ważną rolę odgrywa jednak niema Anna, emanacja wyrzutów sumienia i symbol pamięci o popełnionych grzechach. Porzucona kochanka nie żyje, ale don Juan za wszelką cenę stara się oszukać przeznaczenie i, nie negując bynajmniej faktu jej śmierci, posługuje się słowem „sen”. Łatwiej zaakceptować obecność Hypnosa niż Tanatosa, ale los został już przesądzony. Bezpośrednią konfrontację z komandorem poprzedzają złowrogie znaki:

Czyjeż rysy srogie rosną w szkłach,

W zwierciadlanych szkłach nieruchomieją?

(w. 13-14)

następnie (wers 20) znak-symbol Sądu Ostatecznego: „W odpowiedzi, w śnieżnej mgle, trąbka gra (...)”. Wreszcie Kamienny Gość przybywa:

Przelatuje, bryzgiem świateł tnąc mrok,

Motor czarny i cichy jak sowa.

Po komnatach huczy głucho, grzmi miarowo,

Idącego komandora krok...

(w. 21-24)

i rozlega się bicie zegara, symbolizujące osadzony w kontekście chrześcijańskim moment Bożego sądu. Pomiędzy pierwszym a ostatnim uderzeniem wahadła posąg przemawia:

Drzwi na oścież... Z lodowatej mgły

Jak chrapliwy gong zegara brzmi pytanie:

- Na wieczerzę zapraszałeś, Don Juanie?

Oto masz mnie. Jestem gotów. A ty?

(w. 25-28)

Ostatnie uderzenie w sposób zarówno metaforyczny, jak i paradosłowny obrazuje zbliżający się moment śmierci rozpustnika:

Tylko zegar grzmi ostatni raz,

W groźnym, rannym, huczy gong tumanie:

Na śmiertelne twoje gody Anna wstanie.

Anna wstanie w śmierci twej czas.

(w. 37-40) 
Wspomnienie o "grzmiącym” zegarze pozostaje w znaczeniowej relacji z archanielską trąbą, która po raz kolejny (i ostatni) informuje don Juana o czekającym go losie. Rozpaczliwe wzywania śniącej wieczny sen Anny - fundamentu nagle przebudzonej (!) wiary - na nic się zdadzą; porzucona kochanka dostąpi chwały zmartwychwstania w momencie śmierci wiarołomnego kochanka.

$\mathrm{Na}$ koniec chciałabym raz jeszcze zatrzymać się przy postaci ożywionego posągu nagrobnego, którego „imię” nakazuje w odmienny sposób definiować jego status ontologiczny w utworach Błoka i Lieberta. Pisownia wielką literą w rosyjskim oryginale jest konstytutywną cechą jednostkowego bohate$\mathbf{r a}^{45}$, w przeciwieństwie do typu postaci (mała litera) obecnej w wierszu autora Drugiej ojczyzny. Pod uwagę trzeba wziąć pierwsze wydanie Kotysanki jodtowej $(1932)^{46} \mathrm{i}$ uznać pisownię tam zastosowaną za obowiązującą. Zdecydowałam się zwrócić na to uwagę ze względu na występujące czasami rozbieżności w późniejszych wydaniach ${ }^{47}$. Liebertowski komandor to ożywiona, kamienna i wymierzająca sprawiedliwość / dokonująca zemsty figura nagrobna, noszą$\mathrm{ca}-\mathrm{w}$ zależności od inwencji twórczej kolejnych dramatopisarzy - imię don Gonzala (Zwodziciel z Sewilli i Kamienny Gość Tirsa de Moliny) lub na przykład Statuy/Posągu (La Estatua De Don Gonzalo w Don Juanie Tenorio Zorrilli). Typ postaci - na wzór typu postaci donżuana - pozostaje de facto ten sam. I chociaż - jak sądzę - w kategoriach przypadku należy postrzegać decyzję, którą podjął Liebert, wyzwalając się z ram językowego reżimu, może rzucić to nowe światło na interpretację polskiego utworu, któremu autor (być może jednak nie do końca nieświadomie?) nadał charakter uniwersalny, zdecydowanie odcinając się od jednej wersji mitu.

\section{Bibliografia}

Balcerzan E., Pisarze polscy o sztuce przektadu 1440-1974. Antologia, Poznań 1977. Barański Z., Aleksander Btok [w:] Literatura rosyjska w zarysie, red. Z. Barański, A. Semczuk, Warszawa 1976.

Bieńkowski Z., Legenda i poezja Lieberta [w:] J. Liebert, Poezje, Warszawa 1963. Błok A., Dzienniki 1901-1921, tłum. M. Leśniewska, Kraków 1974.

Błok A., Kroki Komandora, tłum. K.A. Jaworski, „Kamena” 1946, nr 8-10. Błok A., Poezje, oprac. S. Pollak, Kraków 1981.

45 Biorę pod uwagę słowo „Komandor” obecne w rosyjskim wierszu. Niemniej jednak zarówno w polskim tłumaczeniu, jak i w oryginale oraz w Dziennikach Błoka jest mowa o krytycznym przyjęciu przez Burienina Kroków komandora.

46 J. Liebert, Kotysanka jodtowa, dz. cyt.

${ }^{47}$ Na przykład w 1946 roku na łamach „Kameny” opublikowano Liebertowski przekład z Błoka, w którym w 24 wersie jest mowa o idącym „Komandorze”. 
Całbecki M., „Czarna kropla nieskończoności”. Fenomen lęku w poezji Jerzego Lieberta, Wtadystawa Sebyty i Aleksandra Rymkiewicza, rozdział: „Jerzy Liebert”, Jerzy Liebert, - - - Harmonia, przemoc i ironia jako egzystencjaty twórczości Jerzego Lieberta, Wrocław 2008.

Carpentier A., Święto wiosny, tłum. J. Carlson, Warszawa 1997.

Dudin M., Rzecz o Aleksandrze Btoku, „Literatura Radziecka” 1980, nr 11.

Jaworski K.A., Kroki Komandora, „Kamena” 1946, nr 8-10.

Kot S., Poezja lęku, „Poezja” 1978, nr 10.

Kott J., Don Juan, albo o pożądaniu, „Zeszyty Literackie” 1994, nr 47.

Kott J., Katolicyzm liryki Lieberta, „Przegląd Współczesny” 1935, nr 155.

Kubaszczyk J., Przektad jako przedmiot przedstawiający: ku ontologicznej definicji przektadu, „Przekładaniec” 2016, nr 32.

Kułakowski S., Trzy mitości Aleksandra Btoka [w:] K.A. Jaworski, W kręgu Kameny, Lublin 1973.

Legeżyńska A., Interpretacja translatorska w polskiej serii ttumaczeń „Dwunastu” Aleksandra Btoka, „Studia Rossica Posnaniensia” 1979, nr 11.

Libera A., Madame, Kraków 2008.

Liebert J., Kotysanka jodtowa, Warszawa 1932.

Liebert J., Listy do Agnieszki, oprac. S. Frankiewicz, Warszawa 2002.

Liebert J., Pisma zebrane, t. 1: Poezja-proza, oprac. S. Frankiewicz, Warszawa 1976.

Liebert J., Poezje, wstęp B. Ostromęcki, Warszawa 1983.

Misiniec S., Ślady na niebie. Duchowa droga Jerzego Lieberta, Kraków 1997.

Molière, Don Juan czyli Kamienny Gość, tłum. T. Boy-Żeleński, Kraków 2003.

Molina T. de, Zwodziciel z Sewilli i Kamienny Gość, tłum. M. Pabisiak, Wrocław 2000.

Nowaczyński P., Ktopoty z kogutem. Z dziejów poetyckiego obrazowania, „Twórczość” 2000, nr 3.

Nowaczyński P., Liebert w polskiej liryce religijnej, „Znak” 1971, nr 10.

Nowaczyński P., O miejscu Lieberta w polskiej poezji religijnej [w:] tegoż, Studia z literatury XX wieku, Lublin 2004.

Od Łomonosowa do Jewtuszenki, wybór, tłum. K.A. Jaworski, Lublin 1972.

Pękacki S., O liryce Jerzego Lieberta, „Twórczość” 1965, nr 12.

Plutarch, Moralia, rozdział: O odwlekaniu kary przez bogów, tłum. Z. Abramowiczówna, Warszawa 1988.

Podhorski-Okołów L., W obronie nowych rymów, „Skamander” 1926, nr 44-46.

Pollak S., Postowie [w:] A. Błok, Poezje, oprac. S. Pollak, Kraków 1981.

Pomirowski L., Nowa literatura w nowej Polsce, Warszawa 1933.

Poźniak T., Aleksander Btok w kręgu spraw polskich, „Literatura Radziecka” 1980, nr 11.

Sławińska I., Groza stowa (o poezji Jerzego Lieberta), „Znak” 1949, nr 2.

Sobieska A., Wokót Aleksandra Btoka. Z dziejów polskich fascynacji kultura i literatura rosyjska, rozdział: Pożoga i wir-Jerzy Liebert o chtystowskich „Ćwiczeniach pokutnych", Warszawa 2015. 
Szczepan-Wojnarska A.M., „...Z ogniem będziesz się żenit”. Doświadczenie transcendencji w życiu i twórczości Jerzego Lieberta, Kraków 2003.

Szymak-Reiferowa J., Jak Btok brzmi po polsku?, „Literatura Radziecka” 1980, nr 11. Szymborska W., Lektury nadobowiazkowe, „Życie Literackie” 1977, nr 13.

Wspótczesne teorie przektadu. Antologia, red. M. Heydel, P. Bukowski, Kraków 2009. Zorrilla J., Don Juan Tenorio, wolny przekład S. Miłaszewskiego, Warszawa 1925. 